University of Michigan Law School

University of Michigan Law School Scholarship Repository

Law \& Economics Working Papers

$1-1-2013$

\title{
A Presumptively Better Approach to Arbitrability
}

John A. E. Pottow

University of Michigan Law School, pottow@umich.edu

Jacob Brege

University of Michigan Law School, jbrege@umich.edu

Tara J. Hawley

University of Michigan Law School, thawley@polsinelli.com

Follow this and additional works at: https://repository.law.umich.edu/law_econ_current

Part of the Contracts Commons

\section{Working Paper Citation}

Pottow, John A. E.; Brege, Jacob; and Hawley, Tara J., "A Presumptively Better Approach to Arbitrability" (2013). Law \& Economics Working Papers. 88.

https://repository.law.umich.edu/law_econ_current/88

This Article is brought to you for free and open access by University of Michigan Law School Scholarship Repository. It has been accepted for inclusion in Law \& Economics Working Papers by an authorized administrator of University of Michigan Law School Scholarship Repository. For more information, please contact mlaw.repository@umich.edu. 


\section{THE \\ CANADIAN \\ BUSINESS LAW \\ JOURNAL}

REVUE
CANADIENNE DU
DROIT DE
COMMERCE

March/mars 2013

Volume 53, No. 3

ARTICLES

A PRESUMPTIVELY BETTER APPROACH TO ARBITRABILITY

John A.E. Pottow, Jacob Brege, and Tara J. Hawley*

One of the most complex problems in the arbitration field is the question of who decides disputes over the scope of an arbitrator's purported authority. Courts in Canada and the United States have taken different approaches to this fundamental question of "arbitrability" that necessarily arises when one party disputes the contractual validity of the underlying "container" contract carrying the arbitration clause. If arbitration is a creature of contract, and contract is a product of consensual agreement, then any dispute that impugns the underlying consent of the parties to the container contract implicates the arbitration agreement itself (i.e., no contract, no arbitration agreement).

The U.S. approach of "separability" dates back a half-century to a Supreme Court case that was controversial when it was decided and remains so today. The Supreme Court has added several more decisions trying to clarify its arbitratbility rules within just the past few years. The Canadians too have tried to sort out this mess, seizing upon the hoary legal distinction between law and fact, also offering recent Supreme Court pronouncements. Neither country's approach is normatively or functionally satisfying.

After discussing and critiquing the two approaches comparatively, we offer our own proposal. We too deploy legal presumptions, but in our case we focus on what we contend are the two most relevant criteria:

* John A.E. Pottow is professor of law, University of Michigan; Jacob Brege and Tara J. Hawley are both 2012 J.D. graduates of the University of Michigan Law School. Thanks to workshop participants at the Universities of Michigan and Toronto. 
(1) the nature of the legal challenge to the underlying container contract, and (2) the type of contract at issue. Challenges to consent in contract formation and contracts involving adhesion should be specially scrutinized by the courts before carting parties off to arbitration, whereas commercial agreements between sophisticated actors should presumptively be for arbitral resolution, even for "constitutive" challenges to the underlying contract.

\section{INTRODUCTION}

Arbitration is often espoused as a faster and simpler alternative to litigation, but it is beset with an array of jurisdictional and theoretical challenges. This article looks at one such problem: the thorny question of "arbitrability." An arbitrability dispute arises when parties to a contract with an arbitration provision have a dispute not just on the subject matter of the contract itself (e.g., was Clause Four breached?), but on the quasi-jurisdictional question of whether their dispute falls under the arbitration clause (e.g., do Clause Four disputes fall under the agreement to arbitrate?). Indeed, one of the most difficult arbitrability questions is the meta-dispute of who decides - court or arbitrator - such a quasi-jurisdictional dispute (e.g., should the arbitrator or a judge get to decide as a contractual interpretation matter whether Clause Four disputes are subject to the arbitration provision?). Arbitrability is at its most problematic when a "constitutive" challenge is made to a contract, such as a claim of fraud or unconscionability, because such claims undermine the very foundation of the underlying contract that contains the arbitration provision.

Taking a comparative stance, focusing particularly on the United States and Canada, this article offers a unique approach to the "Who Decides?" question of arbitrability that has bedeviled arbitration commentators for years, by combining elements of the approaches of both jurisdictions. The article proceeds in several stages. Part II outlines the U.S. approach, starting with the rule of separability that was established in Prima Paint v. Flood \& Conklin Manufacturing Company, ${ }^{1}$ and later developed and refined in subsequent case law. Part III turns to the Canadian Supreme Court's recent wadings into the arbitrability waters: Dell Computer Corp. v. Union des Consommateurs, ${ }^{2}$ describing a different approach to questions of arbitrability (one that is based on the

1. 388 U.S. 395 (1967).

2. (2007), 284 D.L.R. (4th) 577, [2007] 2 S.C.R. 801 (S.C.C.) . 
distinction between legal and factual disputes), including its first implementation in Seidel v. TELUS Communications Inc. ${ }^{3}$ Finally, Part IV offers a more nuanced tack than the categorical routes taken on both sides of the border. The suggested approach turns on the type of dispute and the type of contract, proposing jurisdictional presumptions based on those classifications.

\section{ARBITRABILITY IN THE UNITED STATES}

The concept of arbitrability - the question whether a dispute over arbitration is itself arbitrable - presents the complex and important question whether the parties to a contract containing an arbitration clause should be required to raise a meta-dispute over the contested scope of that clause before an arbitrator or a judge. ${ }^{4}$ The root of the problem lies in the fact that arbitration is a function of contract and therefore of voluntary agreement. ${ }^{5}$ Thus, if the parties did not agree to arbitrate a specific dispute (or quarrel over whether they did), one can see the attraction of saying that these meta-disputes must be resolved by a court as a condition precedent to arbitration. Only after a court confirms that the parties did indeed agree to waive their rights to dispute resolution in a courtroom can one be comfortable stripping the parties of their baseline juridical rights and shipping them off to arbitration. On the other hand, the whole point of arbitration is to facilitate streamlined dispute resolution and get away from judges; marching off to court to clear the underbrush of a threshold dispute may kill the very purpose for which the parties sought arbitration in the first place (even though one party now resists its reach): nonjudicial and speedy resolution of legal disagreements. ${ }^{6}$

3. (2011), 329 D.L.R. (4th) 577, 2011 SCC 15 (S.C.C.).

4. This article does not explore the broader question of when certain legal disputes cannot be resolved by arbitrators as a matter of public policy. Although many jurisdictions deem certain disputes "non-arbitrable," see generally Robert Kovacs, "A Transnational Approach to the Arbitrability of International Insolvency Proceedings in International Arbitrations," paper presented to International Insolvency Institute (Paris, France, June, 2012), available: $<$ http://www.iiiglobal.org/component/jdownloads/viewdownload/391/ 5914.html > , the embrace of arbitration is so robust in the United States that this form of "arbitrability" challenge almost never arises under U.S. law. See infra, footnote 9 .

5. See e.g., Rent-A-Center, West, Inc. v. Jackson, 130 S. Ct. 2772 (2010) ("The FAA reflects the fundamental principle that arbitration is a matter of contract."); First Options of Chicago, Inc. v. Kaplan, 514 U.S. 938 (1995), p. 943 ("Arbitration is simply a matter of contract between the parties; it is a way to resolve those disputes - but only those disputes - that the parties have agreed to submit to arbitration."). 
Law \& Economics W orking Papers, Art. 88 [2013]

\section{Prima Paint and the Rule of Separability}

The problem of arbitrability came to the fore in Prima Paint $v$. Flood \& Conklin Manufacturing Company, ${ }^{7}$ in which one party claimed fraud in the inducement of a sales contract that contained an arbitration clause. (Arbitration commentators refer to the broader agreement within which the specific arbitration provision is contained as the "container" contract.) ${ }^{8}$ The Federal Arbitration Act (FAA) renders "valid, irrevocable, and enforceable" a "written provision in any maritime transaction or a contract evidencing a transaction involving commerce," "save upon such grounds as exist at law or in equity for the revocation of any contract." ${ }^{9}$ When the buyer brought a rescission suit in federal district court, the seller sought to compel arbitration under s. 3 of the FAA, citing the arbitration clause. ${ }^{10}$

The buyer responded that there could be no arbitration because his claim of fraud in the inducement of the container contract rendered the whole agreement voidable, including any putative agreement to arbitrate embedded therein. ${ }^{11}$ The seller retorted that whether there was fraud was a dispute that could readily be adjudicated by the arbitrator. ${ }^{12}$ Moreover, if there was no fraud as the seller unsurprisingly insisted there was not - then to drag him off to court, with all litigation's cost and delay, would be to subject him to the very evil he was trying to avoid by including an arbitration clause in his sales contract. ${ }^{13}$ The buyer replied that if there was fraud - as the buyer unsurprisingly insisted there was the arbitration clause should get no enforcement as it flowed from an invalid contract. ${ }^{14}$ And so on ad infinitum.

6. See, e.g., Solymar Investments, Ltd. v. Banco Santander S.A., 672 F.3d 981 (11th Cir. 2012), p. 997 and note 17 (noting that requiring a court to investigate the failure of an alleged oral condition precedent "would require a district court to invade the province of the arbitrator" and that "such an inquiry would necessitate extensive discovery and expend limited judicial resources").

7. Supra, footnote 1.

8. See Michael H. Brady, "Exclusive Separability? Arbitrability and the Contract Formation Defense" (2009), 28 Rev. Litig. 913, p. 917; David Horton, “Arbitration as Delegation" (2011), 86 N.Y.U. L. Rev. 437, p. 449.

9. 9 U.S.C.A. $\$ 2$ (2006).

10. Prima Paint, supra, footnote 1, at p. 401.

11. Prima Paint, supra, at p. 408 (Black J. dissenting) ("Prima simply contended that there was never a meeting of minds between the parties.").

12. Prima Paint, supra, at p. 399.

13. See Prima Paint, supra, at p. 404.

14. See Prima Paint, supra, at p. 408 (Black J. dissenting). 
The U.S. Supreme Court thus had to answer "whether a claim of fraud in the inducement of the entire contract [containing an arbitration clause] is to be resolved by the federal court, or whether the matter is to be referred to the arbitrators." 15 In crafting its answer, the court divided disputes into two kinds of challenges a grievant might bring to contractual validity. First, a claimant might challenge the whole of the contract, as was the case in the dispute before it, where the buyer alleged fraud in the inducement of the entire container contract. ${ }^{16}$ Second, a claimant might challenge just the validity of the arbitration agreement itself, but not the rest of the broader contract. ${ }^{17}$ The court read s. 4 of the FAA $^{18}$ to require the first kind of challenge to go before an arbitrator but the second to go before a judge. ${ }^{19}$ Thus, if the arbitration provision itself is alleged to be fraudulently induced ("That clause? Oh, that's nothing to worry about; we would never insist on arbitration - just sign the contract!"), then the claimant is entitled to make his case before a judge. But in the case of a generalized challenge to the container contract as a whole, for fraud in the inducement or similar grounds of contractual invalidity, the dispute is consigned to the arbitrator. The justification for this division is that an undifferentiated dispute over the contract as a whole provides no reason to call into question the validity of the arbitration agreement itself. ${ }^{20}$ In Prima Paint, for example, the dispute was with the seller's alleged misrepresentation of its financial condition in negotiating the sale of the business. ${ }^{21}$ The fraud (assuming it occurred) would have had nothing to do with whether the parties consented to have business disputes heard by an arbitrator. In effect, the court held that an

15. Prima Paint, supra, at p. 402.

16. Prima Paint, supra, at pp. 403-404.

17. Prima Paint, supra, at p. 403.

18. 9 U.S.C. $\S 4$ reads in pertinent part:

The court shall hear the parties, and upon being satisfied that the making of the agreement for arbitration or the failure to comply therewith is not in issue, the court shall make an order directing the parties to proceed to arbitration in accordance with the terms of the agreement.

19. Prima Paint, supra, footnote 1, at pp. 403-404:

Accordingly, if the claim is fraud in the inducement of the arbitration clause itself an issue which goes to the "making" of the agreement to arbitrate - the federal court may proceed to adjudicate it. But the statutory language does not permit the federal court to consider claims of fraud in the inducement of the contract generally.

20. In concluding thus, the court read the term "contract" in s. 2 of the FAA to refer to the contract to arbitrate itself. Therefore, arbitration was properly compelled unless this contract was not "valid, irrevocable, and enforceable." Prima Paint, supra, at p. 412.

21. Prima Paint, supra, p. 398. 
Law \& Economics W orking Papers, Art. 88 [2013]

agreement to arbitrate could be severed - as a matter of substantive federal law under the FAA - from the rest of the impugned contract, thus preserving the jurisdiction of the arbitrator to hear even a dispute that would go to the underlying enforceability of the contract that conferred her arbitral jurisdiction. ${ }^{22}$ The rule of "separability," and hence of presumptive arbitrator competence to hear disputes of arbitrability, was born into U.S. case law. ${ }^{23}$

Prima Paint was controversial from the moment it was decided. A vigorous dissent rejected what it found to be the majority's "fantastic" holding, ${ }^{24}$ allowing arbitrators, who "need not even be lawyers," to "adjudicate the legal validity of the contract - an arguable violation of due process. ${ }^{25}$ Instead, the dissent argued: ${ }^{26}$

Congress and the framers of the Act were at great pains to emphasize that non-lawyers designated to adjust and arbitrate factual controversies arising out of valid contracts would not trespass upon the courts' prerogative to decide the legal question of whether any legal contract exists upon which to base an arbitration.

Scholars have similarly criticized separability, ${ }^{27}$ some calling for the outright reversal of Prima Paint ${ }^{28}$ others questioning its

22. Prima Paint, supra, at p. 405.

23. See Alan Scott Rau, "Everything You Really Need to Know About 'Separability' in Seventeen Simple Propositions" (2003), 14 Am. Rev. Int'l Arb. 1, pp. 34-35 ("The thrust of the doctrine of 'separability,' then, is to recognize the probable competence of the arbitrators, by presuming that they have been entrusted by the parties with the power to make a virtually non-reviewable decision on the issue of validity."). One author has called the result of such separability "implied consent." Richard C. Reuben, "First Options, Consent to Arbitration, and the Demise of Separability: Restoring Access to Justice for Contracts with Arbitration Provisions (2003), 56 S.M.U. L. Rev. 819

24. Prima Paint, supra, footnote 1, at p. 407 (Black J. dissenting).

25. Prima Paint, supra.

26. Prima Paint, supra, at p. 408. Further, while the dissent did not argue about consent specifically, it did argue that the separability of any one provision from a larger agreement should be determined by the intention of the parties. "Whether a number of promises constitute one contract (and are non-separable) or more than one is to be determined by inquiring "whether the parties assented to all the promises as a single whole ..." Supra, at p. 424 (Black J. dissenting) (quoting United States v. Bethlehem Steel Corp., 315 U.S. 289 (1941), p. 298).

27. For an overview of various sources of critique, see Reuben, supra, footnote 23, p. 841; see also Larry J. Pittman, "The Federal Arbitration Act: The Supreme Court's Erroneous Statutory Interpretation, Stare Decisis, and A Proposal for Change" (2002), 53 Ala. L. Rev. 789 (for a statutory-interpretation-based critique).

28. See, e.g., Nancy R. Kornegay, "Prima Paint to First Options: The Supreme Court's Procrustean Approach to the Federal Arbitration Act and Fraud" (20012002), 38 Hous. L. Rev. 335, p. 338. 
compatibility with contract law, ${ }^{29}$ and still others contesting its logical soundness. ${ }^{30}$ Conversely, some arbitration enthusiasts have defended separability, praising it as providing "the best baseline rule in the context of the FAA, because it guarantees that arbitration clauses will be enforceable, notwithstanding . . . deficiencies in the underlying agreement." ${ }^{31}$ It is safe to say that there has been ongoing debate since the day Prima Paint was decided. The Supreme Court itself has had to wade back into the fray multiple times, clarifying the contours of the federal presumption of arbitrability flowing from the separability rule. ${ }^{32}$

\section{First Options and the Clear Statement Rule}

In 1993, the Supreme Court faced another arbitrability issue in First Options v. Kaplan. ${ }^{33}$ First Options had entered into an agreement to work out debts with Manuel Kaplan, his wife, Carol Kaplan, and Manuel's wholly owned investment company, MK Investments, Inc. (MKI). ${ }^{34}$ The workout agreement consisted of four separate documents to compromise debts. ${ }^{35}$ After MKI lost an

29. See, e.g., Lawrence A. Cunningham, "Rhetoric Versus Reality in Arbitration Jurisprudence: How the Supreme Court Flaunts and Flunks Contracts" (2012), 75 Law \& Contemp. Prob. 129 (criticizing the Supreme Court's arbitration rhetoric as incongruous with the court's arbitration analysis); Stephen J. Ware, "Employment Arbitration and Voluntary Consent" (1996), 25 Hofstra L. Rev. 83, p. 131:

[I]mposing duties based on speculations about what the parties would have voluntarily consented to is profoundly different from imposing duties based on what the parties did, in fact, voluntarily consent to. The former has no place in contract law while the latter is the essence of contract law.

30. See, e.g., Richard L. Barnes, "Prima Paint Pushed Compulsory Arbitration Under the Erie Train" (2007), 2 Brook. J. Corp. Fin. \& Com. L. 1 ("If a contract is a legal nullity, it would seem intuitive that any lesser part would amount to nothing as well.”).

31. Kirsten Weisenberger, "From Hostility to Harmony: Buckeye Marks A Milestone in the Acceptance of Arbitration in American Jurisprudence" (2005), 16 Am. Rev. Int'l Arb. 551, p. 558.

32. Indeed, this presumption of arbitrability is qualified by a "reverse presumption" from the First Options opinion (discussed immediately infra), in which ambiguity over an expressly contracted provision for arbitrability is interpreted strictly.

The law treats silence or ambiguity about the question who (primarily) should decide arbitrability differently from the way it treats silence or ambiguity about the question whether a particular merits related dispute is arbitrable because it is within the scope of a valid arbitration agreement - for in respect to this latter question the law reverses the presumption.

First Options v. Kaplan, supra, footnote 5, pp. 944-945 (internal quotations omitted).

33. Supra, footnote 5.

34. First Options, supra, at p. 940.

35. First Options, supra. 
additional $\$ 1.5$ million under the workout, First Options accelerated the debt and seized and liquidated MKI's assets, demanding payment from the Kaplans for the deficiency. ${ }^{36}$ When its demand went unsatisfied, First Options sought arbitration. ${ }^{37}$ Of the four workout documents, only one contained an arbitration agreement, and though this agreement was signed by MKI, it was never signed by either of the Kaplans. ${ }^{38}$

The Kaplans thus denied that any dispute to which they were a party was arbitrable and petitioned the arbitrators accordingly. ${ }^{39}$ The arbitrators decided that the arbitrability meta-dispute of the Kaplans based on lack of signatory authority was itself arbitrable (i.e., that the arbitrators could properly decide the question); found against the Kaplans on that meta-dispute (namely, that they could be forced to arbitrate the corporate dispute notwithstanding their lack of signature); and ultimately ruled for First Options on the merits of the workout dispute in arbitration. ${ }^{40}$ The Kaplans then asked a federal district court to vacate the arbitration award pursuant to s. 10 of the FAA, and First Options requested confirmation of the award pursuant to s. $9 .{ }^{41}$ The district court confirmed the award, but an appellate court reversed. ${ }^{42}$

On further appeal, the Supreme Court framed the issue as "who has the primary power to decide arbitrability?" 43 That question, the court reasoned, "turns upon what the parties agreed about that matter." 44

If . . the parties did not agree to submit the arbitrability question itself to arbitration, then the court should decide that question just as it would decide any other question that the parties did not submit to arbitration, namely, independently. ${ }^{45}$

Accordingly, "courts should not assume that the parties agreed to arbitrate arbitrability unless there is 'clea[r] and unmistakabl[e]'

36. First Options, supra.

37. First Options, supra.

38. First Options, supra, at p. 941.

39. First Options, supra. Manuel Kaplan participated in the arbitration as the sole owner of MKI which is presumably why he addressed his signature dispute to the arbitrators whom he claimed lacked authority to bind him.

40. First Options, supra.

41. First Options, supra.

42. First Options, supra.

43. First Options, supra, at p. 943.

44. First Options, supra.

45. First Options, supra. 
evidence that they did so." 46 The court noted the signature dispute and concluded that ${ }^{47}$

because the Kaplans did not clearly agree to submit the question of arbitrability to arbitration [and their pleading of the arbitrability dispute before the arbitrators did not constitute a waiver], the Court of Appeals was correct in finding that the arbitrability of the Kaplan/First Options dispute was subject to independent review by the courts.

The court based this conclusion on the finding that "First Options cannot show that the Kaplans clearly agreed to have the arbitrators decide (i.e., to arbitrate) the question of arbitrability." 48

The court's opinion in First Options engendered more scholarly comment $^{49}$ and, worse, more confusion among lower U.S. courts. ${ }^{50}$ Some scholars saw the rules of Prima Paint and First Options as in desperate need of harmonization, ${ }^{51}$ while others rejected any tension. ${ }^{52}$ One scholar went so far as to declare First Options the death knell of Prima Paint, and as such "the demise of separability," which is "appropriate as a matter of theory, doctrine, and practicality." 53 At the root of the problem were two seemingly opposed propositions: first, that arbitration agreements are presumed separable, and thus even attacks on the constitutive validity of the contract as a whole, such as fraud in the inducement, are presumed to go to arbitration for resolution (a presumption of arbitrability, per Prima Paint); and second, that because arbitration is a creature of contract, parties must have a clear and unmistakable contractual intent to assign arbitrability

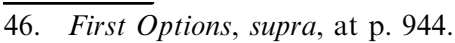

47. First Options, supra, at p. 947 (alterations added).

48. First Options, supra, at p. 946.

49. See, e.g., Reuben, supra, footnote 23 , p. 870

50. For example cases see Alan Scott Rau, "The Arbitrability Question Itself" (1999), 10 Am. Rev. Int'l Arb. 287, p. 332, note 121; see also Sphere Drake Ins. Ltd. v. All American Ins. Co., 256 F.3d 587 (7th Cir. 2001), p. 590 (noting that "Prima Paint ... sits uneasily alongside AT\&T Technologies and First Options").

51. See, e.g., Stephen J. Ware, "Arbitration Law's Separability Doctrine After Buckeye Check Cashing, Inc. v. Cardegna" (2007), 8 Nev. L.J. 107, pp. 113-114: [The] holding of First Options indicates that the separability doctrine does not apply to the issue of whether particular parties "agreed to arbitrate" because the separability doctrine gives arbitrators the power to decide issues subject only to the deferential standard of review in FAA section 10.

52. See Rau, supra, footnote 23, at p. 96 ("First Options adds nothing that is particularly fresh or compelling — nothing that we could not already have assumed.").

53. Reuben, supra, footnote 23 , at p. 872 . 
questions to an arbitrator (a presumption against arbitrability, per First Options).

In 2006, the Supreme Court weighed back in and reaffirmed its commitment to the rule of separability in Buckeye Check Cashing, Inc. v. Cardegna. ${ }^{54}$ In that case, John Gardegna and Donna Reuter, signatories of a short-term lending contract with an arbitration clause, sought certification of a class action, alleging that "Buckeye charged usurious interest rates and that the Agreement violated various Florida lending and consumerprotection laws, rendering it criminal on its face." 55 Buckeye moved to compel arbitration. ${ }^{56}$ The trial court denied the motion, holding that "a court rather than an arbitrator should resolve a claim that a contract is illegal and void ab initio." 57 While the Florida Supreme Court agreed - holding the tainted arbitration agreement void by its situation within an illegal contract - the U.S. Supreme Court granted leave and reversed. ${ }^{58}$ In reversing the Florida Supreme Court, the U.S. Supreme Court held fast to Prima Paint: ${ }^{59}$

First, as a matter of substantive federal arbitration law, an arbitration provision is severable from the remainder of the contract. Second, unless the challenge is to the arbitration clause itself, the issue of the contract's validity is considered by the arbitrator in the first instance. Third, this arbitration law applies in state as well as federal courts.

Thus, in one respect, Buckeye went even further than Prima Paint. In Prima Paint, the fraud in the inducement challenge based on false accounting (arguably) said nothing about the parties' amenability to have commercial disputes resolved by an arbitrator. As such, arbitration of the fraud claim was permitted. In Buckeye, the court held that, notwithstanding a rule of state law that made the contract containing the arbitration clause illegal - unenforceable per se - arbitration, as agreed to in that contract, could still go forward as a matter of pre-emptive federal law under the FAA. ${ }^{60}$

\footnotetext{
54. 546 U.S. 440 (2006).

55. Buckeye Check Cashing, supra, at p. 442.

56. Buckeye Check Cashing, supra.

57. Buckeye Check Cashing, supra, at p. 443.

58. Buckeye Check Cashing, supra, at pp. 443 and 449. The U.S. Supreme Court had jurisdiction because even though the Florida Supreme Court is the final expositor of Florida contract law, the FAA is a federal statute with pre-emptive federal effect and subject to final interpretation by the U.S. Supreme Court.

59. Buckeye Check Cashing, supra, at pp. 445-446.

60. Buckeye Check Cashing, supra.
} 
Pottow et al.:

\section{Arbitrability's Zenith: Rent-A-Center and the Russian Dolls}

The power of the separability rule rose to its zenith just recently in Rent-A-Center, West, Inc. v. Jackson. ${ }^{61}$ The dispute before the Supreme Court for the first time raised the issue of a container agreement that was itself an arbitration agreement. Jackson, an employee of Rent-A-Center, had signed an agreement to arbitrate all disputes arising from his employment contract with Rent-ACenter. ${ }^{62}$ This agreement - separate from his employment agreement - contained a provision termed by the court a "delegation provision," which further agreed to submit to arbitration any challenge to the enforceability of the larger arbitration agreement within which it was contained. ${ }^{63}$ When Jackson brought suit for employment discrimination under federal law, Rent-A-Center moved to stay proceedings and compel arbitration pursuant to the arbitration agreement. ${ }^{64}$ Jackson then argued that the arbitration agreement was unconscionable under Nevada law and hence could not bind him. ${ }^{65}$ Rent-A-Center, relying on the delegation provision, argued that any challenge to the container arbitration agreement as a whole had to be submitted to arbitration. ${ }^{66}$

The federal district court dismissed Jackson's claim, citing not only Prima Paint but also the rule of First Options in finding that the agreement by means of the delegation clause "clearly and unmistakenly [sic]" conferred upon the arbitrator authority to decide the validity of the arbitration agreement. ${ }^{67}$ The federal appellate court reversed on the grounds that, although the text of the agreement in isolation was clear in this delegation, Jackson's unconscionability claim called into question the assent necessary to enforce the agreement containing this textual delegation. This "threshold question of unconscionability," it concluded, must

61. Supra, footnote 5; see generally Cunningham, supra, footnote 29, p. 140 (calling Rent-A-Center, West, Inc. v. Jackson the "apotheosis of the separation of arbitration jurisprudence from contract law").

62. This agreement included "claims for discrimination" and "claims for violation of any federal . . law." Rent-A-Center, supra, at p. 2775.

63. Rent-A-Center, supra, at p. 2777.

64. Rent-A-Center, supra, at p. 2775.

65. Rent-A-Center, supra.

66. Rent-A-Center, supra. Neal R. Troum characterized the question facing the court as a "Gordian knot." "Another View of Rent-A-Center, Arbitration and Arbitrability: Who Is Watching the Watchmen?" (2010), 28 Alternatives to High Cost Litig. 184, p. 185.

67. Rent-A-Center, supra, at p. 2775 (internal quotations omitted). 
therefore be "for the court." ${ }^{68}$ The Supreme Court, in a sharply divided opinion, reversed again, dismissing Jackson's claim and compelling arbitration. ${ }^{69}$

The majority's analysis began with FAA's s. 2, which ensures the validity of an agreement to arbitrate "save upon such grounds as exist at law or in equity for the revocation of any contract." 70 Drawing upon Prima Paint, it then applied the separability analysis to the delegation provision, considering the larger arbitration agreement in which it was nested the container contract. $^{71}$ In order to get to court, the majority concluded, Jackson would had to have pled a deficiency in the delegation clause specifically. ${ }^{72}$ Jackson never mentioned the delegation provision in his submissions, instead insisting that the arbitration agreement as a whole was unfair. ${ }^{73}$ The fact that the container contract was itself an arbitration agreement, under this analysis, was of no consequence; a validity challenge to the whole is separable and can be arbitrated. ${ }^{74}$

The dissent criticized the majority's reasoning, raising two principal objections. First, under the First Options clear statement rule of arbitrability, "[c]ourts should not assume that the parties agreed to arbitrate arbitrability unless there is clear and unmistakable evidence that they did so."75 So-called "gateway" issues - such as those that speak to whether there has been free assent to the contract - must necessarily be decided prior to enforcement of a contractual arbitration agreement. ${ }^{76}$ Because unconscionability would undermine or even negate the assent necessary to agree to arbitration, the dissent complained (agreeing with the Court of Appeals), there could be no "clear and unmistakable" voluntary agreement to arbitrate arbitrability under First Options. ${ }^{77}$

68. Jackson v. Rent-A-Center West, Inc., 581 F.3d 912 (2009), at p. 917.

69. Rent-A-Center, supra, footnote 5, at p. 2781.

70. The text of the statute provides that:

[A] written provision in ... a contract evidencing commerce to settle by arbitration a controversy thereafter arising out of such contract ... shall be valid, irrevocable, and enforceable, save upon such grounds as exist at law or in equity for the revocation of any contract. [9 U.S.C. \$2]

71. Rent-A-Center, supra, footnote 5, at pp. 2777-2779.

72. Rent-A-Center, supra, at p. 2779.

73. Rent-A-Center, supra.

74. Rent-A-Center, supra.

75. Rent-A-Center, supra, at p. 2783 (Stevens J. dissenting) (quoting First Options of Chicago, Inc. v. Kaplan, supra, footnote 5, at p. 944).

76. Rent-A-Center, supra, at p. 2782.

77. Rent-A-Center, supra, at p. 2785. 
Worse, in the dissent's view, was the majority's perversion of the Prima Paint rule of separability. Instead of being irrelevant, the fact that the underlying container agreement concerned "exclusively arbitration" should have "ma[de] all the difference in the Prima Paint analysis."78 A challenge to the whole contract, rather than being indeterminate, as it was in Prima Paint, must on the contrary necessarily have been an objection to arbitration. Recall the rationale of Prima Paint was that the buyer's claim that the seller cooked the books said nothing about the buyer's amenability or antipathy toward arbitration of business disputes. Here, Jackson was challenging an arbitration agreement as unconscionable, which could mean nothing other than Jackson's aversion to arbitration. The dissent thus protested that Prima Paint was being turned on its head. ${ }^{79}$

Moreover, the dissent contended, the majority misapplied Prima Paint with respect to the relevant agreement to which it pertained. In the case before the court, there were actually three levels of agreement: the employment contract ("the employment agreement"), the separately signed agreement to arbitrate disputes under the employment contract ("the arbitration agreement"), and the agreement to arbitrate disputes about the arbitration agreement contained within that arbitration agreement ("the arbitrability agreement"). The majority considered the arbitrability agreement to be separable from the arbitration agreement, with Jackson's attack to the whole of the latter being fatal to his (unspecified) objections to the former. The dissent, by contrast, felt Jackson's specific objections to the arbitration contract were quintessentially what Prima Paint would distinguish from a generalized challenge to the employment contract as a whole and hence permit to be raised before a judge. Calling one clause of that arbitration agreement a separate "arbitrability agreement," which would require its own specific challenge under Prima Paint to open the courtroom door, had the ridiculous consequence in the dissent's view of creating an infinite separability regression, plucking agreements from agreements and creating a "Russian nesting doll" effect. ${ }^{80}$

Like its predecessors, Rent-A-Center has engendered strong criticism among scholars, but it is the Supreme Court's most recent

\footnotetext{
78. Rent-A-Center, supra, at p. 2782.

79. See Rent-A-Center, supra.

80. Rent-A-Center, supra, at p. 2786.
} 
pronouncement on separability. ${ }^{81}$ As such, the approach in the United States is now one of strong arbitrability: it is almost impossible to plead a claim of contractual infirmity that will be heard by a court. ${ }^{82}$ Under Prima Paint, as affirmed and amplified by Rent-A-Center, litigants are almost invariably presumed to have consented to arbitrators' adjudications of meta-disputes on the scope and validity of arbitration agreements. These include such fundamental matters as contractual unconscionability, if the challenges (as most such challenges necessarily and logically will) impugn the whole of the broader container contract. ${ }^{83}$

\section{Granite Rock's Refinement (and Retrenchment?)}

Three days after Rent-A-Center was decided, the U.S. Supreme Court handed down Granite Rock Co. v. International Brotherhood of Teamsters. ${ }^{84}$ In a much less-fractured opinion, the court reiterated and endorsed a distinction adverted to in the opening footnote of Buckeye: namely, that the presumption of arbitrability only arises after a court has concluded that a proper contract with an arbitration clause has "come into existence" in the first place. In strong language, it characterized judicial confirmation of a properly formed contract prior to ordering arbitration as being a "first principle" of its case law and a logical consequence of arbitration being a creature of consensual contract.

The facts of the case were idiosyncratic. Granite Rock got into a dispute with its labour union regarding a work stoppage that occurred alongside the renegotiation of a new collective bargaining agreement (CBA). The stoppage took place in a possible no-man's land occurring after the old CBA expired but (arguably) before the new CBA took effect. Although both CBAs contained arbitration

81. See, e.g., Jennifer Schulz, "Arbitrating Arbitrability: How the U.S. Supreme Court Empowered the Arbitrator at the Expense of the Judge and the Average Joe" (2011), 44 Loy. L.A. L. Rev. 1269, p. 1270 (calling for congressional action).

82. See, e.g., Carlo Marichal, "Arbitrating Issues You Might Not Have Agreed to: Rent-A-Center, West, Inc. v. Jackson" (2011), 12 Fla. Coastal L. Rev. 485, p. 500 (arguing that the decision "essentially precludes the employee from seeking redress from the courts").

83. At least one scholar discussing pre-dispute mandatory arbitration agreements has gone so far as to say that "an argument can be made that, when arbitration clauses are involved, federal courts have, in effect, gone beyond promoting neutrality in contracting and have created a special class of 'super enforceable' contracts." Sandra F. Gavin, "Unconscionability Found: A Look at Pre-Dispute Mandatory Arbitration Agreements 10 Years after Doctor's Associates, Inc. v. Casarotto" (2006), 54 Clev. St. L. Rev. 249, p. 250.

84. 130 S.Ct. $2847(2010)$ 
Pottow et al.:

clauses, Granite Rock contended that the work stoppage dispute could not go to arbitration before answering the threshold question whether this dispute arose, in the words of the agreements, "under the [CBA]." This answer in turn depended on the new CBA start date, which was itself in dispute given a ratification anomaly. If there was no ratified CBA during the work stoppage, reasoned Granite Rock, there was no arbitration clause to enforce regarding that dispute. But the parties hotly disagreed over when that ratification date was and so needed that dispute resolved first.

A federal trial court decided it had jurisdiction to hear the ratification-date question and held a jury trial, which found that the CBA had indeed been ratified before the work stoppage and thus the labour dispute was arbitrable. The court of appeals, however, found that the district court had no jurisdiction over the ratification-date fight in the first place - citing Prima Paint and the strong national policy favouring arbitration of disputes because it was a challenge to the whole of the (CBA) contract, not just the arbitration clause.

In chiding the appellate court for "overreading" its arbitration precedents, the Supreme Court reversed. It approved the trial court's judicial resolution of the ratification-date dispute (which in turn counseled arbitral resolution of the labour dispute). It distinguished Buckeye and like cases as involving a challenge to a container contract that was unquestionably formed - but held illegal ex post under state law (and hence lacking what it called "validity") - from ones, such as the instant cause, about whether a container contract was "ever concluded" in the first place. Far from recognizing a tension with Prima Paint (or Rent-A-Center), the court treated the issue as an entirely distinct question that arises well before the separability rule might ever be invoked.

Although using some terminology interchangeably, the court emphasized a distinction from the Buckeye footnote between "formation" disputes, which it held would be for courts to decide, and "validity" disputes, which would presumptively be for arbitrators under the Prima Paint separability rule. ${ }^{85}$ (It also effectively acknowledged a third type: "enforceability" or "applic-

85. Thomas J. tried to adhere to this approach in the following year's Concepcion case at the Supreme Court, but had to write a separate concurring opinion there, suggesting already some departure from his proposed framework. See $A T \& T$ Mobility LLC v. Vincent Concepcion, 131 S.Ct. 1740 (2011), pp. 1753-1756 (Thomas J. concurring). 
Law \& Economics W orking Papers, Art. 88 [2013]

ability" disputes, which it held would be presumptively for courts to decide, under a "reverse presumption," but which could be consigned to arbitrators in the presence of a "valid provision specifically committing such disputes to an arbitrator." ${ }^{86}$

Granite Rock was thus an attempt by the court to clear up some of the tensions in its case law, which perhaps explains why it reached out to resolve the case. (As the dissenting justices pointed out, given the fact that the new CBA expressly made itself retroactive in effect, the ratification-date fight was ultimately unnecessary, as any dispute should have been arbitrable, because there was no no-man's land problem at all; the majority's only response to this point was that this seemingly dispositive retroactivity argument was procedurally forfeited by belated pleading!)

On the one hand, Granite Rock seems to have scaled back Prima Paint's separability rule, by deeming "formation" disputes to be simply outside its scope. On the other hand, the reach of this carveout is quite narrow, with offered examples being the lack of signatory authority seen in First Options, or the lack of mental capacity to assent referenced in the Buckeye footnote. Pointedly, neither the fraud of Prima Paint nor the unconscionabilty of RentA-Center were seen as "formation issues" under the Granite Rock carve-out, even though both arguably imperil meaningful consent to contract. Thus, the underlying normative critique of Prima Paint remains unanswered: what to do about carting parties off to arbitration who do not fully consent by contract to such a fate.

86. In First Options, the court explained: "Courts should not assume that the parties agreed to arbitrate arbitrability unless there is "clea[r] and unmistakabl[e]' evidence that they did so." At p. 944 (citing $A T \& T$ Technologies, Inc. v. Communications Workers of America, 475 U.S. 643 (1986), p. 649). Some courts appear to struggle with these possibly overlapping distinctions. See, e.g., Janiga v. Questar Capital Corp., 615 F.3d 735 (7th Cir. 2010), pp. 738 and 742 (suggesting any existence dispute could be conferred to an arbitrator and interpreting an "enforceability" dispute, such as an argument of procedural unconscionability, as one that would be presumptively for arbitration and not, as Granite Rock's discussion of enforceability would suggest, for courts). In fact, the court in Granite Rock at various points discusses issues of an arbitration agreement's "scope," "enforceability," "consent," and "formation" as threshold matters to be resolved by courts - all distinguished from "validity." Granite Rock, supra, footnote 84 , passim. Needless to say, confusion still abounds; at least one court felt the need to explain why Granite Rock did not overrule Prima Paint! See Solymar Investments, supra, footnote 6, at p. 990, note 9 . 
Pottow et al.:

\section{CANADA'S WAY}

\section{Dell Computer Corp. v. Union des Consommateurs}

The Supreme Court of Canada recently explored issues regarding arbitrability in Dell Computer Corp. v. Union des Consommateurs. ${ }^{87}$ Although the case centered on an issue of statutory interpretation of Québec procedural law, it also offered the court an opportunity, which it took, to weigh in on arbitrability. Analyzing this complex case first requires understanding the animating statutory issue, which in turn requires brief summary of the case's bizarre facts. On Friday, April 4, 2003, Dell's English-language website incorrectly listed wildly low prices for two of its products. ${ }^{88}$ On April 5, 2003, Dell became aware of these mistakes and blocked access to the order pages "through the ordinary [web] address," but did not take down the (outdated) pages where the incorrect prices were still listed. ${ }^{89}$ Oliver Dumoulin was able to access the outdated page with the incorrect prices through a "deep link" e-mailed to him by an unknown individual. ${ }^{90}$ The deep link went directly to the flawed page, bypassing the rest of the Dell website, stymying the blocks Dell erected to fix the error. Delighting computer hackers and anarchists everywhere, Dumoulin ordered on this webpage a computer for a well-below-market price of $\$ 89 .{ }^{91}$

When Dell contacted Dumoulin to inform him that it would not honour the order, Dumoulin paired with the Union and sought authorization of a class action for consumer protection law violations. ${ }^{92}$ Dell sought arbitration pursuant to an arbitration clause contained in the terms and conditions of the sale contract. ${ }^{93}$ Complicating matters legally, a governing Québec statute forbade waivers of court jurisdiction (arbitration is a waiver of court jurisdiction) in consumer disputes involving a "foreign element." 94 Hence, a novel statutory question involving arbitration arose:

87. Dell Computer Corp. v. Union des Consommateurs, supra, footnote 2.

88. The Axim X5 $300 \mathrm{MHz}$ handheld computer was listed at $\$ 89$ instead of $\$ 379$ and Axim X5 $400 \mathrm{MHz}$ handheld computer was listed at \$118 instead of \$549. Dell Computer, supra, para. 4.

89. Dell Computer, supra.

90. Dell Computer, supra.

91. Dell Computer, supra.

92. Dell Computer, supra, para. 5.

93. Dell Computer, supra.

94. Dell Computer, supra, para. 6. This statute would be an example of a policy-based arbitrability restriction. See supra, footnote 4. 
whether an arbitration agreement invoking U.S. arbitration rules contains a "foreign element" that renders the arbitration clause invalid under Québec procedural law. ${ }^{95}$ The trial court concluded that it does. ${ }^{96}$ It reasoned that because the arbitration agreement referred the dispute to arbitration rules connected with the United States, it contained a "foreign element" and thus constituted an impermissible waiver of court jurisdiction pursuant to Civil Code of Québec $^{97}$ (C.C.Q.) art. 3149. ${ }^{98}$ The court accordingly denied arbitration under the flawed contract (and, incidentally, also authorized the class action against Dell). ${ }^{99}$

The Supreme Court of Canada reversed this statutory construction, holding that "[u]nlike the foreign element, which suggests a possible connection with a foreign state, arbitration is an institution without a forum and without a geographic basis." 100 The statutory question having been resolved, the court then addressed arbitrability: under Québec law, should the trial court have decided this statutory question in the first place, or should Dell have been able to compel Dumoulin to present it to an arbitrator? ${ }^{101}$

95. Dell Computer, supra, paras. 6-11.

96. Dell Computer, supra, para. 6.

97. L.R.Q., c. C-1991.

98. Dell Computer, supra, footnote 2. Art. 3149 C.C.Q. also provides:

A Québec authority also has jurisdiction to hear an action involving a consumer contract or a contract of employment if the consumer or worker has his domicile or residence in Québec; the waiver of such jurisdiction by the consumer or worker may not be set up against him. See Dell Computer, supra, para. 180.

99. Dell Computer, supra, para. 5. Dell has its Canadian head office in Toronto and a place of business in Montreal. Supra, para. 4.

100. Dell Computer, supra, para. 51. Even if they are foreign rules, the court reasoned, "[t]he rules become those of the parties, regardless of where they are taken from." Supra, para. 52. Just before the Dell Computer decision was handed down, Québec passed a law banning arbitration agreements in consumer contracts, perhaps as a legislative response to the lower court opinion. See Shelley McGill, "Consumer Arbitration after Seidel v. Telus" (2011), 51 C.B.L.J. 187, p. 191 (referencing art. 11.1 of the Québec Consumer Protection Act, R.S.Q., c. P-40.1). Curiously, the court declined to dismiss the pending appeal as moot in the face of this enactment. Its justification for the continued expenditure of judicial resources in this context was that Québec's ban was not retroactive and so the specific case at bar required resolution (beyond the resolution already provided by the trial and appellate courts). Dell Computer, supra, footnote 2, paras. 117120.

101. Dell Computer, supra, para. 68. 
Pottow et al.:

\section{Who Decides? Competence-Competence}

The Dell court outlined two schools of thought on the question of "who decides" arbitrability, both taken from international commercial law. ${ }^{102}$ The first sends the dispute directly to court in order to avoid duplication. After all, "since the court has the power to review the arbitrator's decision regarding his or her jurisdiction, why should the arbitrator be allowed to make an initial ruling on this issue?" 103 The second, known as "competencecompetence," grants arbitrators the capacity to rule on their own jurisdiction out of concern with preventing delay tactics. ${ }^{104}$

The competence-competence approach is commonly used (as indeed is the doctrine of separability) in international commercial arbitration. ${ }^{105}$ The widespread use of these doctrines can be attributed to the fact that "[t]he doctrines, taken together, ensure that the parties' intent to arbitrate any disputes that arise out of their international contractual relationship is effectuated without undue court interference." 106 The ensuing certainty of arbitrator authority, proponents contend, facilitates international commerce. $^{107}$ The competence-competence principle has also been divided into what are called its "positive" and "negative" applications. ${ }^{108}$ "Positive" competence-competence accords arbitrators the authority to decide their own authority, but not in any way that precludes parallel court adjudication of the same question. Thus, positive competence-competence "means that . . . arbitrators are empowered to rule on their own jurisdiction; they are not required to stay [their] proceeding to seek judicial guidance." 109 Negative competence-competence goes further and "holds that in order to allow arbitrators to rule on their own

102. Dell Computer, supra, para. 69.

103. Dell Computer, supra.

104. Dell Computer, supra, para. 70.

105. See Robert H. Smit, "Separability and Competence-Competence in International Arbitration: Ex Nihilo Nihil Fit? Or Can Something Indeed Come from Nothing?" (2002), 13 Am. Rev. Int'l Arb. 19, p. 19 ("These two doctrines have appropriately been called the conceptual cornerstones of international arbitration as an autonomous and effective form of international dispute resolution.").

106. Ibid.

107. Ibid., at pp. 22-23.

108. John J. Barcelo III, "Who Decides the Arbitrators' Jurisdiction? Separability and Competence-Competence in Transnational Perspective," (2003) 36 Vand. J. Transnat'l L. 1115, p. 1124.

109. Ibid. 
jurisdiction ... as an initial matter, court jurisdiction ... should be constrained." 110

Section 943 of Québec's Code of Civil Procedure ${ }^{111}$ codifies a form of positive competence-competence, providing that "[t]he arbitrators may decide the matter of their own competence." 112 Section 943.1 softens this broad grant of arbitrability power, however, by qualifying that "[i]f the arbitrators declare themselves competent during the proceedings, a party may within thirty days of being notified thereof apply to the court for a decision on that matter." 113 Finally, s. 940.1 directs the court to "refer [parties to an arbitration agreement] to arbitration on the application of either of them unless the case has been inscribed on the roll or it finds the agreement null." 114 The majority in Dell read this text to incorporate the "null and void, inoperative or incapable of being performed" test from the New York Convention ${ }^{115}$ to allocate arbitrability, which is essentially an application of positive competence-competence. ${ }^{116}$ Thus, arbitrators are given the initial capacity to decide their own competence, but courts have concurrent jurisdiction based on the possible nullity of the arbitration agreement.

\section{Judicial Review of Who Decides}

The Dell court then discussed the question that logically follows: if a court may trump the arbitrator's competence-competence to decide an arbitrability dispute if the contract is "null and void" under s. 940.1, how intensive should the judicial scrutiny of voidness be? (Similarly, if a court may review an arbitrator's assessment of jurisdiction under s. 943.1, what standard of review should apply?) As one scholar frames the question, if courts are

110. Ibid. France, for example, which popularized the concept of negative competence-competence, interprets the rule as meaning if "the arbitral tribunal has not yet been seized of the matter," unless the agreement is "manifestly null," the courts must decline jurisdiction. Ibid., at pp. 1124-1125.

111. R.S.Q., c. C-25.

112. Dell Computer, supra, footnote 2, para. 79.

113. Dell Computer, supra.

114. Dell Computer, supra.

115. Convention on the Recognition and Enforcement of Foreign Arbitral Awards, 330 U.N.T.S. 3, T.I.A.S. No. 6997, [1986] Can. T.S. No. 43.

116. Dell Computer, supra, para. 83:

However, since this provision was adopted in the context of the implementation of the New York Convention (the words of which, in art. II(3), are "null and void, inoperative or incapable of being performed"), I do not consider a literal interpretation to be appropriate. 
allowed to set aside arbitration agreements that are "null and void" under the New York Convention: ${ }^{17}$

Are the courts required to inquire into the merits of the existence and validity of the arbitration agreement or must they restrict their control to a prima facie verification that the arbitration agreement exists and is valid ...?

Dumoulin argued for "what has been called the "comprehensive approach' following which the objections to the validity of the arbitration agreement should be dealt with comprehensively before the matter is referred (or not) to arbitration."118 Dell argued for the less intrusive prima facie approach, by which a "court seized of a referral application should refer the matter to arbitration upon being satisfied on a prima facie basis that the action was not commenced in breach of a valid arbitration agreement."119

The court's response was somewhat mixed. While adopting an approach that it later contended was more consistent with the prima facie approach, ${ }^{120}$ it seemed determined - presumably on the mission of providing structure and guidance to lower courts to establish a categorical methodology. The court interpreted the null and void standard to require most arbitrability disputes to go to arbitration (subject to judicial review under positive competence-competence) but to permit some to stay in court, depending on the type of dispute. In so doing, it considered several ways to draw this categorical distinction. The most interesting one it considered in some detail drew a line between "applicability" and "validity." 121 Such an approach would grant courts the power to resolve arbitrability challenges that go to the "validity" of the container agreement, while arbitrators would resolve claims that go merely toward its "applicability." The court ultimately rejected this approach, however, noting that while workable, it was not well supported by decisions of Québec courts. ${ }^{122}$

117. Emmanuel Gaillard, "Prima Facie Review of Existence, Validity of Arbitration Agreement", The New York Law Journal, December 1, 2005, at p. 7, available at $<$ http://www.nylj.com $>$ or $<$ http://www.shearman.com/ia_040308_14/>.

118. Dell Computer, supra, footnote 2, para. 169 (Bastarache and LeBel JJ. dissenting).

119. Dell Computer, supra, para. 168 (Bastarache and LeBel JJ. dissenting).

120. Dell Computer, supra, para. 83.

121. Dell Computer, supra, para. 82. This suggestion comes from Frédéric Bachand, L'intervention du juge canadien avant et durant un arbitrage commercial international (Cowansville, Québec, Yvon Blais, 2005).

122. Dell Computer, supra, footnote 2. 
The court instead selected a standard based on the distinction between law and fact. ${ }^{123}$ Under this approach, pure questions of law regarding arbitrability stay with the courts, while mixed questions of law and fact (and straight questions of fact) go to the arbitrator. ${ }^{124}$ The court found this approach to be "faithful to art. 943 C.C.P. and to the prima facie analysis test that is increasingly gaining acceptance around the world." 125 The Canadian law and fact distinction addresses some of the dissent's due process concern in Prima Paint - that is, the misgiving that questions of law could be sent directly to arbitrators based on illegal contracts. ${ }^{126}$ (Recall the dissent in Prima Paint worried about questions of law being sent to arbitrators who may not even have legal training.) $)^{127}$ Thus, the Canadian approach perhaps remedies the concern of the Prima Paint dissent that purely legal issues will be thrown into arbitration when consent to arbitration itself is questioned, by reserving questions of law for the courts. The Canadian approach does not, however, answer the broader concern of "unconsented" contracts forcing a party into arbitration. As the dissent was equally troubled in Prima Paint, ${ }^{128}$

If Prima's allegations are true, the sum total of what the Court does here is to force Prima to arbitrate a contract which is void and unenforceable before arbitrators who are given the power to make final legal determinations of their own jurisdiction.

The Canadian approach would send to arbitration an arbitrability dispute in which the purported lack of contractual consent is factually contested, which surely must be a non-trivial subset of such disputes. ${ }^{129}$

The fact-law distinction, therefore, does not resolve the concerns that most irked those sympathetic to the Prima Paint dissent. Indeed, in the Dell case itself, Dumoulin's argument required "not only an interpretation of the law, but also a review of the

123. Dell Computer, supra, paras. 84-85.

124. Dell Computer, supra, para. 85.

125. Dell Computer, supra, para. 83. The law/fact distinction of null and void review is surely animated by the belief that this will also instruct the degree of appellate deference when a court sits in review of an arbitral award under s. 943 C.C.P. Law/fact distinctions are oft-used in crafting appellate standards of review.

126. See supra, section II(1).

127. Ibid.

128. Prima Paint, supra, footnote 1, at p. 425 (Black J. dissenting).

129. For example, the court cites Kingsway Financial Services Inc. v. 118997 Canada Inc., [1999] Q.J. No. 5922, J.E. 2000-225 (Que. C.A.), as an example in which the Court of Appeal simply referred the case to arbitration when buyer sued seller on the basis of error induced by fraud. Dell Computer, supra, footnote 2, para. 81 . 
documentary and testimonial evidence introduced by the parties." ${ }^{130}$ Based on the fact-law test adopted by the court, the matter should have been referred to arbitration. ${ }^{131}$ Presumably a challenge to consent like the unconscionability argument forwarded in Rent-A-Center would similarly require intense factual analysis and would likewise wind up before an arbitrator under the Canadian approach. Accordingly, although the Canadians articulated a different test from Prima Paint, the same outcome that concerns those who believe arbitration is only legitimate if based on a voluntary contractual agreement remains: a claimant who insists she never consented to an underlying contract purportedly showing her agreement to arbitrate can be forced to plead her consent-based grievance to an arbitrator she may have never authorized. ${ }^{132}$

\section{Redux: Seidel v. TELUS Communications Inc.}

Having settled on a Canadian approach, the Supreme Court of Canada jumped back in again with its divided judgment in Seidel $v$. TELUS Communications Inc. ${ }^{133}$ which once more involved the arbitrability of a consumer contract dispute. ${ }^{134}$ The case was brought by Seidel, a customer of TELUs's cellular phone services, who claimed that TELus falsely represented how it would calculate air-time for billing purposes in its contract. ${ }^{135}$ Her complaint alleged, among other things, entitlement to relief under the British Columbia Business Practices and Consumer Protection Act ${ }^{136}$ (BPCPA), which explicitly confers trial court jurisdiction by assuring aggrieved parties they "may bring an action in Supreme Court." 137 TELUS attempted to stay the court proceedings and proceed to arbitration "pursuant to s. 15 of the [Commercial Arbitration

130. Dell Computer, supra, at para. 88.

131. Dell Computer, supra.

132. Although, to be sure, the judicial review statutorily accorded arbitrability decisions in Canada makes the issue less stark than Prima Paint's rule, which is coupled with only Spartan judicial review under the FAA.

133. Seidel v. TELUS Communications Inc., supra, footnote 3.

134. Seidel v. TELUS Communications Inc., supra.

135. Seidel v. TELUS Communications Inc., supra, at para. 10.

136. S.B.C. 2004 , c. 2.

137. Seidel v. TELUS Communications Inc., supra, footnote 3, at para. 1. Section 172 of the BPCPA reads in pertinent part that "a person other than a supplier, whether or not the person bringing the action has a special interest or any interest under this Act or is affected by a consumer transaction that gives rise to this action, may bring an action in Supreme Court." Supra, at para. 5 (emphasis in original). 
Law \& Economics W orking Papers, Art. 88 [2013]

Act]," based on the arbitration clause in the cellular services contract signed by Seidel. ${ }^{138}$ Seidel resisted the stay by claiming the BPCPA's specific conferral of a right to bring an action in the B.C. Supreme Court abrogated any purported waiver of that right under an arbitration clause.

The trial court held that Dell Computer, which was decided under Québec law, did not control a British Columbia case, ${ }^{139}$ and so Siedel's case should be governed by the controlling B.C. precedent of MacKinnon v. National Money Mart Co. ${ }^{140}$ ("Mackinnon 2004"), a case holding that arbitration agreements become "inoperative" under the CAA if a class action is certified. ${ }^{141}$ Because the certification motion remained pending, the court deferred consideration of TELUS's request for a stay to compel arbitration until it could be seen whether a class would be certified and Mackinnon 2004's rule barring arbitration would be invoked. It therefore did not need to reach the question of BPCPA abrogation of the arbitration clause. The B.C. Court of Appeal reversed and held that the CAA and Québec law (as interpreted in Dell) both "stemmed" from the New York Convention, and thus contained no substantive differences. Accordingly, Dell functionally overruled Mackinnon 2004. ${ }^{142}$ The Court of Appeal, no longer bound by Mackinnon 2004, held against Seidel on her statutory abrogation claim, reasoning that arbitration clauses are not waivers of substantive rights (only waivers of forum) and so are in no way relevant to the BPCPA. ${ }^{143}$ The appellate court thus

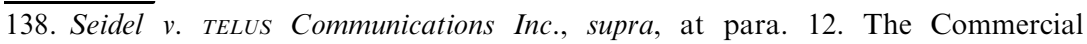
Arbitration Act, R.S.B.C. 1996, c. 55 (CAA), states in pertinent part that: If a party to an arbitration agreement commences legal proceedings in a court against another party to the agreement in respect of a matter agreed to be submitted to arbitration, a party to the legal proceedings may apply, before or after entering an appearance and before delivery of any pleadings or taking any other step in the proceedings, that court to stay the legal proceedings. Supra, at para. 21.

139. U.S. readers of this Canadian journal need occasional reminder that the Supreme Court of Canada issues authoritative pronouncements of provincial law as a common law court. Dell Computer, supra, footnote 2, was a Québec case and so the Supreme Court's pronouncement was technically an interpretation of the law of Québec.

140. (2004), 50 B.L.R. (3d) 291, 2004 вCCA 473 (B.C. C.A.).

141. Seidel v. TELUS Communications Inc., supra, footnote 3, at para. 14. The Supreme Court of Canada refers to that MacKinnon case as "MacKinnon 2004." Supra, at para. 14.

142. Seidel v. TELUS Communications Inc., supra, at para. 17.

143. Seidel v. TELUS Communications Inc., supra, at para. 18. The BPCPA reads in pertinent part: "Any waiver or release by a person of the person's rights, benefits or protections under this Act is void except to the extent that the waiver or release is expressly permitted by this Act." Supra, at para. 21. 
Pottow et al.:

granted TELUS's stay to force Seidel to arbitration as required by the contract. ${ }^{144}$

The Supreme Court of Canada framed the question as one of statutory intent: "whether the BPCPA manifests a legislative intent to intervene in the marketplace to relieve consumers of their contractual commitment to "private and confidential' mediation/ arbitration and, if so, under what circumstances." 145 The majority held that it does. The court noted that several provincial legislatures, such as Québec, Ontario, and Alberta, have legislation that creates "greater or lesser limitations on arbitration clauses in consumer contracts," and so the question was to determine British Columbia's intent. ${ }^{146}$

In terms of arbitrability specifically, the court faithfully followed the categorical law-fact approach of Dell, explaining that the statutory construction question was one of pure law and hence properly before the courts in the first instance. ${ }^{147}$ On the merits, the court further held that s. 172 of the BPCPA "provides a mandate for consumer activists or others, whether or not they are personally 'affected' in any way by any 'consumer transaction," to bring a consumer claim "in Supreme Court." 148 Thus, s. 3 makes any agreement that requires the parties to waive rights provided by the BPCPA (like the right to bring an action in a B.C. Supreme Court) "void," 149 and that rule is indeed substantive. ${ }^{150}$ Reversing the appellate court and setting aside in part the stay, the Supreme Court of Canada decided the BPCPA statutory claims were thus non-arbitrable but any other claims (e.g., common law breach of contract) were subject to the arbitration clause and should "be stayed pursuant to $\mathrm{s} .15$ of the [CAA]."151

144. Seidel v. TELUS Communications Inc., supra, at para. 20

145. Seidel v. TELUS Communications Inc., supra, at para. 2.

146. Seidel v. TELUS Communications Inc., supra, at paras. 25-26. Note that the allocation of power to provincial governments to determine arbitrability matters stands in contrast to the pre-emptive federal approach in the United States of the FAA.

Unlike Quebec and Ontario, which ... ban arbitration of consumer claims altogether, or Alberta, which subjects consumer arbitration clauses to ministerial approval, the B.C. legislature sought to ensure only that certain claims proceed to the court system, leaving others to be resolved according to the agreement of the parties. [Supra, at para. 40]

147. Seidel v. TELUS Communications Inc., supra, at paras. 4 and 19.

148. Seidel v. TELUS Communications Inc., supra, at para. 6.

149. Seidel v. TELUS Communications Inc., supra, at para. 5.

150. "Ms. Seidel possesses a statutory 'right' to take her complaint to the Supreme Court." Supra, at para. 33.

151. Seidel v. TELUS Communications Inc., supra, at para. 7. 
Seidel thus reaffirms Dell's categorical approach to arbitrability, although it teases at a subject-matter overlay. That is, because the contracts at issue were consumer arbitration contracts falling under s. 172 of the BPCPA, they were not arbitrable. But that decision was not grounded in a substantive policy of protecting consumers; rather, it was an antiseptic question of statutory interpretation, which suggests that common law doctrines (such as, e.g., unconscionability) have no role to play in the arbitrability analysis unless and until implemented by a legislative enactment. ${ }^{152}$ The court made clear that "[a]bsent legislative intervention, the courts will generally give effect to the terms of a commercial contract freely entered into, even a contract of adhesion, including an arbitration clause." ${ }^{153}$ As one commentator confirms, by providing exceptions only for "legislative intervention" or ones not "freely entered into," the Seidel court "hints that only procedural unconscionability could affect the enforcement of the arbitration clause, implicitly rejecting all submissions of substantive unfairness." 154 Interestingly for American comparison, the Supreme Court also touched on separability, taking an opposite tack from the arbitration-protective approach of Prima Paint. It found that the unenforceable class action waiver "was not severable from the arbitration clause as a whole." 155

Seidel was far from unanimous. The dissent accused the majority of hostility towards arbitration, resistance it claimed was "couched as an exercise in statutory interpretation of the BPCPA."156 It reminded that, under competence-competence, because "arbitrators should be the first to consider challenges to their jurisdiction, the expressions 'void', 'inoperative' and 'incapable of being performed' should be interpreted narrowly." 157 Further, the dissent argued that the analysis of voidness and inoperability should not be used to "sidestep the competencecompetence principle." 158 The dissent, however, did agree with the majority that the question whether s. 172 provides a substantive

152. "What is clear after Seidel is that the Supreme Court will not preserve wide access to the courts for consumers subject to one-sided contracts of adhesion; it abdicates that responsibility to the provincial legislatures." McGill, supra, footnote 100, p. 187.

153. Seidel v. TELUS Communications Inc., supra, footnote 3, at para. 2.

154. McGill, supra, footnote 100 , at p. 189 , note 63 .

155. Seidel v. TELUS Communications Inc., supra, footnote 3.

156. Seidel v. TELUS Communications Inc., supra, at para. 101.

157. Seidel v. TELUS Communications Inc., supra, at para. 117.

158. Seidel v. TELUS Communications Inc., supra, at para. 119. 
Pottow et al.:

right to a judicial forum is a pure question of law to be considered first by the court rather than by the arbitrator, and so also reaffirmed the law-fact distinction of arbitrability established by Dell. ${ }^{159}$

\section{REFOCUSING THE DEBATE: SUGGESTIONS FOR A BETTER APPROACH}

Turning from the comparative to the normative, we propose two criteria on which to base arbitrability presumptions. The first criterion is the classification of the arbitrability dispute. Consider a container employment contract with an arbitration agreement therein. An arbitrability question might arise regarding specific contractual language (e.g., what does "employment dispute" mean?). Or a dispute might arise regarding the contract's scope (e.g., are these tasks within the scope of employment?). There might even be challenges to the legality of the underlying contract, and those challenges might variously be based on substantive illegality (e.g., usuriousness), lack of consent to the agreement (e.g., duress), or even lack of a constitutive element to legal enforceability (e.g., no consideration). There might even further be disputes about statutory interpretation (e.g., does this agreement contain a "foreign element"?). In sum, there are myriad ways in which an arbitrability dispute might arise. While there are accordingly multiple ways to carve and classify these disputes, a fundamental distinction exists between those that challenge the legal character of the underlying agreement and those that challenge whether the underlying agreement ever came into existence. ${ }^{160}$

Although this distinction sounds like the one presented in Granite Rock, we have a broader notion of meaningful contract formation that focuses on consent. Existence disputes should chiefly question the underlying consent of the parties, not the formal categories of doctrine, such as, for example, distinguishing

159. Seidel v. TELUS Communications Inc., supra, at para. 141.

160. See Buckeye Check Cashing, supra, footnote 54, p. 444 (distinguishing between challenges on grounds "that directly affect. . . the entire agreement" from those in which "illegality of one of the contract's provisions renders the whole contract invalid"); AT\&T Mobility LLC v. Vincent Concepcion, supra, footnote 85; George A. Bermann, "The 'Gateway' Problem in International Commercial Arbitration" (2012), 37 Yale J. Int'l L. 1, p. 30 ("It does not seem at all unreasonable to require a party who concedes the existence of a contract, but only contests its validity, to have recourse to an arbitral tribunal for a ruling on the validity question."). 
Law \& Economics W orking Papers, Art. 88 [2013]

fraud in the factum from fraud in the inducement. ${ }^{161}$ Pleadings such as mistake, procedural unconscionability, and material fraud $^{162}$ frequently set out to show that, in some basic respect, an agreement never came into being. ${ }^{163}$ Such defenses stand in

161. Indeed, the U.S. Supreme Court itself seems conflicted over where to draw a line. For example, at one point, it implies the СвA dispute in Granite Rock may not have been an existence dispute. Granite Rock, supra, footnote 84, at p. 2856 ("The [formation dispute] is based on when (not whether) the СвA that contains the parties' arbitration clause was ratified and thereby formed."), but then elsewhere rejects this divide, Granite Rock, at p. 2860 ("For purposes of determining arbitrability, when a contract is formed can be as critical as whether it was formed."). But even this proved too strong a statement, so the court hedged yet again in a footnote:

In reaching this conclusion we need not, and do not, decide whether every dispute over a CBA's ratification date would require judicial resolution. We recognize that ratification disputes in labor cases may often qualify as "formation disputes" for contract law purposes because contract law defines formation as acceptance of an offer on specified terms ...

Granite Rock, supra, at p. 2860, note 11. Thus, the court settles on the position that ratification disputes are sometimes formation disputes. The court does conclude in language we find normatively compelling, albeit buried in a footnote and in no way seeming to guide the court's holding: "But it is not the mere labeling of a dispute for contract law purposes that determines whether an issue is arbitrable. The test for arbitrabilty remains whether the parties consented to arbitrate the dispute in question." Granite Rock, supra, at p. 2860, note 11.

The court's "formation" line (rather than a consent-based divide) perhaps draws from the distinction between voidable and void contracts. Consider, for example, the Restatement (Second) of Contracts' different treatment of fraud in the factum from fraud in the inducement, deeming the first to "prevent the formation" of a contract but the second to "render a contract voidable." See Restatement (Second) of Contracts (1981), sections 163 and 164. It could be in this light that the court emphasizes formation. That said, other strands of analysis suggest such a distinction should be irrelevant. See, e.g., Solymar, supra, footnote 6, p. 994, note 13 (discussing the distinction's relevance and suggesting it may be "crucial to determining whether a contract exists for purposes of arbitration," yet adding a "But $c f$." citation immediately thereafter to Buckeye and further noting that "four Supreme Court justices disregard this distinction," citing Rent-A-Center's dissent ("Whether the general contract defense renders the entire agreement void or voidable is irrelevant.")) (ultimately avoiding the question of the distinction's significance).

162. Consider the position taken by more than one court that the fraud in the factum/ fraud in the inducement divide is actually normatively critical. Sphere Drake Ins. Ltd. v. All American Ins. Co., supra, footnote 50:

Fraud in the inducement does not negate the fact that the parties actually reached an agreement.... But whether there was any agreement is a distinct question.... A person whose signature was forged [fraud in the factum] has never agreed to anything.... This is not a defense to enforcement, as in Prima Paint; it is a situation in which no contract came into being. . .

See also Solymar, supra, footnote 6 (recharacterising as a fraud in the inducement claim one "garbed in the trappings of a fraud in the factum claim" to preclude judicial resolution under Prima Paint). Solymar, supra, at p. 994. By any other name, it would still smell as sweet.

163. Beyond the scope of this article is a comprehensive analysis of assent in contract 
contrast to the first type of challenge (legal character disputes), which includes claims that a putative contract is void against public policy or is defective due to a statute of frauds, or perhaps the failure of conditions precedent, i.e., pleadings that admit of a consensual agreement but nevertheless challenge its propriety on other grounds. ${ }^{164} \mathrm{~A}$ classification of the challenge based on these different normative categories is more compelling, we submit, than a pleadings-based division into challenges against "the whole contract" versus "the specific arbitration provision," as adopted in the United States, or on "legal" versus "factual" disputes, as in Canada.

Second, classification should be made not just of the arbitrability dispute but of the underlying contract. Not all contracts are created equal. For example, adhesion contracts are different from those that are bargained for at arm's length by sophisticated parties. Adhesion contracts often involve unequal bargaining power, the weaker of the two parties being unable to negotiate individual terms. ${ }^{165}$ Consent-based challenges to contract formation are not only categorically different from other challenges to enforceability of a contract (our first consideration), but they are especially worrisome in the context of adhesion contracts, where

law. We are inclined to conceive of fraud in the inducement as negativing consent in the same way that fraud in the factum does, but if we envision consent as a continuum, then surely fraud in the factum is "worse" along that continuum. As such, our tentative reaction would be to push back at the cases that see fraud in the inducement as "merely" tainted and reversible consent, but consent nonetheless; we see the normative defect in the meeting of the minds in these cases as much more troubling. For a recent thoughtful treatment, see Margaret Jane Radin's Boilerplate: The Fine Print, Vanishing Rights, and the Rule of Law (Princeton, New Jersey, Princeton University Press, 2012). We concede to be pushing against some established contract law doctrine here. See, e.g., Dialysis Access Center, LLC v. RMS Lifeline, Inc., 638 F.3d 367 (1st Cir. 2011), pp. 378-379 (analyzing Puerto Rican contract law's concept of "dolo" or "dolus," which deems deceit in contract formation as leaving a contract "tainted" but nonetheless still "a contract" and imposing a four-year limitations period for nullification). Candidly, we admit inter-author disagreement over the proper situation of a standalone claim of substantive unconscionability along a consent continuum (i.e., whether it crosses the line of no consent or whether it is merely an instance of an "invalid" or "illegal" consensual contract).

164. The claimant in Buckeye, for example, challenged the contract on the ground of usurious interest rates - a claim that did not relate to consent or formation in any specific way. Supra, footnote 54, at p. 440. See also Solymar, supra, footnote 6, at pp. 997 and note 17 (failure of condition precedent). See generally Bermann, supra, footnote 160 , p. 30 ("It does not seem at all unreasonable to require a party who concedes the existence of a contract, but only contests its validity, to have recourse to an arbitral tribunal for a ruling on the validity question.").

165. See 1 Domke on Com. Arb. $\S 8: 26$. 
autonomy is already on shaky footing. Surely the constitution of the employment contract that Antonio Jackson signed with RentA-Center stands in sharp contrast to that of the sales contract worked out between the businesses of Prima Paint and F\&C. ${ }^{166}$ No one contends Jackson played even a remote role in drafting the substantive provisions of the contract, including the arbitration agreement. Prima and F\&C, by contrast, very well likely bargained for arbitration, specifically and mutually. Consequently, in situations where consent is called into question by an "existence" challenge to contract (following our classification), we might craft appropriate procedural rules, such as presumptions based on the class of contract, to favour or disfavour arbitration. For example, a presumption of consent could attach to arm's-length transactions but be reversed in the context of adhesion contracts. ${ }^{167}$

In thinking about crafting interpretative presumptions based on these considerations, we are also mindful of the consequences of error. Arbitrability errors, we submit, pose a unique threat to nonconsenting parties. To be sure, all contract interpretation errors pose a threat to non-consenting parties; holding a party legally bound to that which he has not consented - under the rubric of contract law - creates what Margaret Jane Radin would call a normative embarrassment. ${ }^{168}$ Unlike discrete contractual provisions, however, such as a condition for performance, or even important ones, such as a price term, arbitration clauses have global effect: they shift all terms of a contract that may fall into dispute out of the judicial forum. ${ }^{169}$ Indeed, dispute of the contested term collapses into the function of the term itself. To

166. For an overview of the evolution of employment contracts under the FAA, see Meredith Goldich, "Throwing Out the Threshold: Analyzing the Severability Conundrum Under Rent-A-Center, West, Inc. v. Jackson" (2011), 60 Am. U. L. Rev. 1673, p. 1686-1689.

167. Some jurisdictions go so far as to prohibit pre-dispute arbitration contracts in the consumer and employment spheres. See Karen Halverson Cross, "Letting the Arbitrator Decide Unconscionability Challenges" (2011), 26 Ohio St. J. on Disp. Resol. 1, p. 35 ("Since 1994, the 27 countries of the European Union have been obligated to maintain national laws prohibiting the enforcement of standardform, pre-dispute arbitration clauses in their consumer contracts.").

168. See Radin, supra, footnote 163. See also Anny Vexler, "Margaret Jane Radin Gives 2011 Grafstein Lecture: Boilerplate is changing our legal universe," University of Toronto, Faculty of Law, News, June 11, 2011, online: < http:// www.law.utoronto.ca/visitors_content.asp?itempath $=5 / 5 / 0 / 0 / 0 \&$ specNews $=954 \&$ cType $=$ NewsEvents $>$.

169. See, e.g., Bermann, supra, footnote 160 , p. 49:

The courts treat arbitrability, in the narrow sense in which I define that term, as a gateway matter, but not because the inquiry has an arbitration-specific character; they do so because it entails the core judicial function of statutory interpretation and 
wit, suppose a price term is contested. Resolution of that dispute, even if resulting in an erroneous outcome, still is heard before a court. Such is the consequence of living in a world with litigation. By contrast, if an arbitration term is contested, the false positive error is profound. All disputes of anything that might go wrong under the contract - ever - are tainted. To be sure, consenting parties are free to waive recourse to trial, but because arbitration clauses change the essence of the containing contract - rendering it in some important sense "extra-judicial" - the consequence of a false-positive mistake is to remove from parties, who could be adhesion contract signatories, all legal protection and oversight. ${ }^{170}$

Accordingly, not only do we contend that challenges to consent are categorically different from other garden-variety challenges to contractual validity - and that in adhesion contracts those concerns are magnified - we also believe that the consequences of falsely holding one to arbitration in the absence of consent in this context are worse than the harms of falsely denying parties arbitration who consented to it. Therefore, in case of doubt involving adhesion contracts, a tie should go against arbitration. We base this conclusion on the belief, especially with regard to the adhesion contracts that permeate the consumer realm, that weaker parties systemically prefer court resolution to private arbitration, notwithstanding its purported efficiency. ${ }^{171}$ This is in part based on empirical assumption and in part on populist belief in a "right," at least in the United States, to public adjudication of grievances

because the issue has a sufficient public policy dimension to warrant early judicial determination.

170. Cf. Prima Paint, supra, footnote 1, p. 414 (Black J. dissenting) (detailing legislative history of the FAA showing support of special protection for weaker parties to adhesion contracts when enforcing arbitration provisions).

171. Such preference may rest on factors such as a perceived arbitrator bias toward companies over the consumer. See Center For Justice and Democracy at New York Law School, "Fact Sheet: Mandatory Binding Arbitration - A Corporate End Run Around the Civil Justice System" (March 5, 2012), online: <http:// centerjd.org/content/fact-sheet-mandatory-binding-arbitration-corporate-endrun-around-civil-justice-system > ; Arbitration Activism: How the Corporate Court Helps Business Evade Our Civil Justice System, A Report by Alliance for Justice, 2011, available at $<$ www.afj.org $>$. Many consumer claims are not viable unless they are aggregated in a class proceeding. Griffin v. Dell Canada Inc. (2010), 315 D.L.R. (4th) 723, 2010 onCA 29 (Ont. C.A.), leave to appeal refused (2010), 316 D.L.R. (4th) vii, [2010] 1 S.C.R. viii (S.C.C.). As the Griffin court noted:

Both academic research and the common sense ... indicate that suppliers and sellers regularly insert arbitration clauses in order to defeat claims rather than out of a genuine desire to arbitrate disputes with consumers. Such disputes often involve small claims that are not individually viable [assuming they are coupled with a commonplace bar on class proceedings]. [Supra, at para. 29, alteration added] 
Law \& Economics W orking Papers, Art. 88 [2013]

(which could be plausibly found variously under Article III, the Seventh Amendment, and the common law). ${ }^{172}$

These foregoing considerations lead us to propose the following new arbitrability presumptions, which can be seen as both a rejection and embrace of the separability doctrine:

1. Existence challenges to adhesion contracts (such as massproduced consumer or employment contracts) should presumptively stay in court for pre-arbitration adjudication.

2. Existence challenges to arm's-length commercial contracts should presumptively be sent to arbitration for resolution.

3. Character challenges in either context should be sent to arbitration. ${ }^{173}$

172. Mandatory arbitration agreements may be at odds with the U.S. Constitution's Seventh Amendment right to a jury trial. At least one author contends that "courts, legislators, policymakers, and the public have paid very little attention to the direct tension between mandatory binding arbitration and the right to a jury trial." Jean R. Sternlight, "Mandatory Binding Arbitration and the Demise of the Seventh Amendment Right to A Jury Trial" (2001), 16 Ohio St. J. on Disp. Resol. 669 , at p. 670. There has been growing U.S. opinion that mandatory arbitration in the consumer and employment context poses significant legal concerns. See Martha Nimmer, "The High Cost of Mandatory Arbitration" (2010), 12 Cardozo J. Conflict Resol. 183, p. 184; Marissa Dawn Lawson, "Judicial Economy at What Cost? An Argument for Finding Binding Arbitration Clauses Prima Facie Unconscionable" (2004), 23 Rev. Litig. 463, at p. 465; Nicole Karas, "EEOC v. Luce and the Mandatory Arbitration Agreement" (2003), 53 DePaul L. Rev. 67, at p. 69. For discussion of the constitutional implications of arbitration clauses invoked by third parties, see Nima H. Mohebbi, "Back Door Arbitration: Why Allowing Nonsignatories to Unfairly Utilize Arbitration Clauses May Violate the Seventh Amendment" (2010), 12 U. Pa. J. Bus. L. 555, at p. 556. For a discussion of arbitration agreements and the right to a jury trial, as well as how adhesion contracts in general (which may include arbitration agreements) affect constitutional rights and issues of consent, see Margaret Jane Radin, supra footnote 163.

173. We add two clarifications of these presumptions. First, they should only apply in court proceedings, such as a Section 2 challenge under the FAA; they should not arise in arbitration itself. A party to an adhesion contract who knowingly and voluntarily proceeds with arbitration should enjoy no presumptions regarding consent; if she later wishes to contend to the arbitrator that the underlying container contract lacked consent, we propose no evidentiary presumption in this context, just as we would propose no presumption that an arm's-length commercial party exercised full consent. Second, the presumptions should probably be rebuttable. As a first cut, we suggest casting them as burdens of production. At the pleading stage, if the party opposing the presumption can produce a genuine dispute of fact, the presumption ends. In the case of adhesion contracts, therefore, if the drafting party can plead facts in court that rebut the presumption against consent (perhaps specific discussion of the contested clause), the arbitrability dispute should be sent to arbitration; in the case of arms-length transactions, a party must plead facts in court that rebut the presumption of consent (such as the presence of a gun) in order for its claim to remain there. 
We elaborate our position. First, perhaps surprisingly, we think the invocation of the separability doctrine articulated in Prima Paint and largely accepted abroad in some contexts can actually be justified in many cases. ${ }^{174}$ In a standard arm's-length transaction, it makes perfect sense to presume the validity of an arbitration agreement imbedded in a container contract that appears otherwise regular on its face, even if a consent-based challenge is brought with respect to that container contract. Since the consent required to bargain for terms between sophisticated parties is generally robust, there is no empirical reason to craft a protective presumption against arbitration, even given our normative concerns. ${ }^{175}$ Indeed, severing a delegation clause from a container agreement that is itself an arbitration contract, such as that found in Rent-A-Center, might also pass muster, at least among sophisticated parties, although to be sure such micro-severance is ungainly. ${ }^{176}$ As for the normative concerns, our populistly animated worries dissipate in this context. There is no reason to think a sophisticated commercial actor is mistakenly or unknowingly forfeiting public adjudication rights. Separability is thus defensible, at least in this arm's-length commercial context. Relatedly, while we agree with the impulse of reserving certain constitutive challenges for judicial resolution seen in Granite Rock, we have doubts whether that should have been the outcome with two sophisticated commercial legal actors, especially when arbitration was heartily endorsed in all versions of the CBA at issue in that case.

But approval in one context, even if an important one, in no way makes us apologists for the crudely undifferentiated approach of Rent- $A$-Center, where separability is the invariable rule regardless of the type of contract and consent-based nature of challenge. Contrast, for instance, adhesion contracts between parties of unequal bargaining power. In such cases, the whole of the terms of a contract are dictated by the stronger party, and consent with respect to any individual term likely stands or falls with consent to the contract as a whole. It is difficult to imagine a situation in which a party can realistically be considered to have consented to a

174. See Rau, supra, footnote 23, pp. 81-82.

175. Cf. Peabody Holding Co., LLC v. United Mine Workers of America, International Union, 665 F.3d 96, (4th Cir. 2012), p. 104 ("A presumption in favor of arbitrability generally vindicates the intent of the contracting parties.").

176. Severing the delegation clause still produces the problem of infinite separability. See Rent-A-Center, West, Inc. v. Jackson, supra, footnote 5, p. 2786 (Stevens J. dissenting). 
Law \& Economics W orking Papers, Art. 88 [2013]

boilerplate term of an adhesion contract if not to that contract in its entirety. ${ }^{177}$ Thus, separability — premised on the idea that just because consent is challenged to one term of the contract (sales terms), there is no reason to think it would be challenged to another (arbitration) — is less justifiable. Such contracts should perhaps be excepted from the separability doctrine altogether. ${ }^{178}$ Yet a policy more solicitous to arbitration - and also worried about the converse error costs of false denials of arbitration might be to have a reverse presumption rather than outright separability exemption. Thus, if a consent-based claim is brought against a contract of adhesion containing an arbitration agreement, that agreement should be severed, but to presume its invalidity, not to maintain it. An adverse party could still bring evidence to establish consent to the arbitration agreement, but it would have to do so specifically with respect to that agreement to compel arbitration. ${ }^{179}$

Still, such a presumption reversal should only apply to existence-based claims under our first criterion of classification. Any claim regarding merely the character of the agreement, such as its incompatibility with public policy, its unenforceability due to a statute of frauds, the failure to fulfill conditions precedent, or any other pleading that admits of an agreement to the contract as a whole, ought to remain subject to separability, even though such a challenge broadly impugns the underlying "validity" of the agreement. This is so, perhaps contentiously for some, even in the context of adhesion contracts. Cabining the presumption in this way avoids concerns of undermining the efficacy of arbitration and likely increases political tolerability. ${ }^{180} \mathrm{~A}$ court that adjudi-

177. See Andrea Doneff, "Arbitration Clauses in Contracts of Adhesion Trap 'Sophisticated Parties' Too" (2010), 2010 J. Disp. Resol. 235, pp. 268-269 (arguing that, with respect to class arbitration, "because most parties who sign pre-dispute clauses have insufficient bargaining power to protect their rights, specific protections need to be built into the law").

178. Many countries do in fact exempt employment and consumer adhesion contracts from their standard approach to deciding validity of an arbitration agreement (such as negative competence-competence). For an overview of these, see Cross, supra, footnote 167, pp. 35-36.

179. On our approach, contractual agreements to arbitrate are not rendered categorically invalid as would be the case under the proposed Arbitration Fairness Act of 2011, H.R. 1873, 112th Cong. (1st Sess. 2011); see also Consumer Protection Act, RSQ, c. P-40.1.

180. See Edna Sussman, "The Arbitration Fairness Act: Unintended Consequences Threaten U.S. Business" (2007), 18 Am. Rev. Int'l Arb. 455, p. 456 (arguing that the proposed Arbitration Fairness Act of 2007, which would render invalid precontractual agreements to arbitrate in consumer, employment or franchise 
cates the validity of a contract will usually also be required to adjudicate the claims of the parties. ${ }^{181}$ Reversing the separability presumption with respect to all validity pleadings would subsequently transform nearly any dispute about arbitrability into a non-arbitrable litigation. Such a blanket rule could do as much violence to contract principles as its inverse. ${ }^{182}$

Reversing separability in adhesion contracts in instances of existence-based challenges also serves to protect the parties better than the law-fact distinction adopted in Canada. Presumably it is not just the right to court adjudication of legal issues that a weaker party requires; existence-based challenges will frequently, if not always, require a finding of fact. Imagine, for a moment, what such a challenge to consent might look like. Is it more likely that the parties stipulate to the use of a gun but then litigate the esoteric legal question whether a gun threat constitutes duress, or is it more likely that parties dispute more fact-dependent questions such as whether a gun was ever used, and if so, whether harm was ever seriously intended, etc.? We think the latter. ${ }^{183}$

Taken together, we therefore submit these arbitrability presumptions to maximize the prospects for achieving the following goals:

1. Arbitration as a general practice not be eroded by an overbroad rule allowing any and all contract validity challenges to be adjudicated by a court (Dell's concern). ${ }^{184}$

2. Consent be honoured in arm's-length transactions such that no party will be unwittingly deprived of mutually bargained-for arbitration (Prima Paint's concern). ${ }^{185}$

disputes from enforcement, would "lead to the abrogation by Congress of contractual terms that reflect international arbitration norms and cause disruption to U.S. business-to-business arrangements").

181. Rent-A-Center, West, Inc. v. Jackson, supra, footnote 5, p. 2779 (Steven J. dissenting) (distinguishing Prima Paint from Jackson for this very reason).

182. See Sussman, supra, footnote 180.

183. Cf. Bailey v. Fed. Nat. Mortg. Ass'n, 209 F.3d 740 (D.C. Cir. 2000), p. 743:

It is unclear in this case whether the District Court's finding that Mr. Bailey never agreed to arbitration is a simple question of fact or a mixed question of law and fact. At first blush, the issue appears to raise a question of fact regarding the parties' intent. Unfortunately, the question is not so simple.

184. The purpose of the FAA was to create a "principle of nondiscrimination in enforcement" of arbitration agreements. Hiro N. Aragaki, Arbitration's Suspect Status (2011), 159 U. Pa. L. Rev. 1233, p. 1237. Thus the FAA "does not demand the impossible feat of placing arbitration agreements on the 'same footing' as all other agreements. Instead, it seeks the more modest goal of leveling the playing field between arbitration and litigation." Hiro N. Aragaki, Equal Opportunity for Arbitration (2011), 58 UCLA L. Rev. 1189. 
3. Consent be honoured in adhesion contracts by protecting the weaker parties in a similar fashion - no party will be shipped off to arbitration without consenting to it (First Options' concern, recognized but not fully resolved by Granite Rock). ${ }^{186}$

Revisiting the descriptive realm, we briefly critique the cases in conclusion. Courtroom challenges brought to contracts with arbitration clauses negotiated at arm's length by sophisticated parties, such as the one implicated in Prima Paint, are rightly rejected unless shown to go specifically to the arbitration agreement. Challenges brought to contracts of employment such as the one at issue in Rent-A-Center should not have been subject to separability in the face of an unconscionability challenge, absent a showing of specific consent. Similarly, consent-based claims against consumer contracts of the type in Dell should also presumptively not have gone to arbitration. And ironically, the formation challenge of Granite Rock regarding the CBA's ratification date would probably have been fine to have been adjudicated by an arbitrator rather than a civil jury. Moreover, as discussed above, a law-fact distinction yields insufficient protection of weaker-party consent. It might protect litigants broadly by reserving for them a judicial forum for the resolution of purely legal questions, but this approach arguably misapprehends the nature of the rights most in need of protection: litigants who did not consent to arbitration would still be forced into it, even if "only" for disputed factual (or mixed law-fact) matters. ${ }^{187}$

\section{CONCLUSION}

Questions of arbitrability are logically and practically challenging. Arbitration clauses affect the most basic operation of

185. Although the court in Prima Paint did not explore the extent to which the nature of the transaction mattered in its analysis, it was clearly worried about denying arbitration to parties who intended it:

This case presents the question whether the federal court or an arbitrator is to resolve a claim of "fraud in the inducement," under a contract governed by the United States Arbitration Act of 1925, where there is no evidence that the contracting parties intended to withhold that issue from arbitration.

Prima Paint Corp. v. Flood \& Conklin Mfg. Co., supra, footnote 1, pp. 396-397.

186. This would remedy the problem of the FAA rendering arbitration agreements "super enforceable" contracts. See Sandra F. Gavin, supra, footnote 83, p. 250.

187. Under our analysis, we would actually have parted ways with the Supreme Court of Canada in Seidel and have allowed the statutory interpretation question to go to arbitration, but we qualify this opinion by noting our lack of engagement in any consent-based challenges Seidel might have also brought in her complaint; none appears to have been litigated in the proceedings. 
contract dispute resolution. They transform contracts through tribunal assignment and pose unique threats to the basic rights and responsibilities of parties to a contract. For this reason, no simple, one-size-fits-all rule is desirable. Recognizing that existence-based challenges occupy a unique status with respect to arbitration agreements, and recognizing also that parties to adhesion contracts constitute a unique category of litigants in need of protection, we believe that certain classes of arbitrability disputes should be presumed to require court adjudication, just as we believe other classes of arbitrability disputes should be presumptively arbitrable. Properly establishing presumptions based on these classifications serves all parties in reflecting the most realistic and normatively attractive default assumptions. Sophisticated parties should not be required to demonstrate consent specifically to an arbitration agreement; general separability is appropriate. Consumers and employees, by contrast, should not be required to show lack of consent specifically to an arbitration agreement through special pleading doctrines; separability should be reversed in such instances. Drawing these lines and properly assigning presumptions based on the nature of the challenge and the relative status of the parties will best protect the expectations of litigants and the tenability of arbitration clauses in general. 